\title{
Comparing alternative media in North and South: the cases of IFIWatchnet and Indymedia in Africa
}

\author{
Fabian Frenzel \\ Bristol Business School, University of the West of England, Bristol, Frenchay Campus, \\ Coldharbour Lane, Bristol BS16 1QY, England; e-mail: fabian.frenzel@uwe.ac.uk
}

\section{Steffen Boehm}

Essex Business School, University of Essex, Wivenhoe Park, Colchester CO4 3SQ, England; e-mail: steffen@essex.ac.uk

\section{Pennie Quinton}

London, England; e-mail: pennieq@yahoo.com

\section{André Spicer}

IROB, Warwick Business School, University of Warwick, Coventry CV4 7AL, England; e-mail: Andre.Spicer@wbs.ac.uk

\section{Sian Sullivan}

Department of Geography, Environment and Development Studies, School of Social Sciences, History and Philosophy, Birkbeck, University of London, 26 Russell Square, London WC1B 5DQ, England; e-mail: s.sullivan@bbk.ac.uk

\section{Zoe Young}

London, England; e-mail: zoe@zoeyoung.net

Received 26 June 2010; in revised form 18 November 2010

\begin{abstract}
Alternative media form an important part of the global mediascape. Research on this phenomenon is, however, often drawn from studies in the 'global North'. In this paper we discuss alternative media in the 'global South', by exploring two case studies of cooperation between Northern and Southern partners: IFIWatchnet in South America, and Indymedia Centre in Africa. We highlight how Northern and Southern partners differed in identity, organizational forms, and accountability. We find that Northern partners were oriented to more 'marginal' identities, fluid organizational structures, and informal structures of accountability. In contrast, Southern activists articulated more 'mainstream' identities, relied on more structured forms, and linked to formalized modes of accountability. The result was often significant clashes over what it meant to be alternative media, how alternative media should be organized, and how people should be held to account. This meant that North-South cooperation was often fraught with struggle. These difficulties are reminiscent of the limitations of creating global cooperation through seeking to spread modes of activist organization developed in the North, which emphasize autonomy, networks, fluidity, and, in some instances, direct action.
\end{abstract}

\section{Introduction}

The arrival and establishment of low-cost media platforms based on information and communication technologies (ICTs) have created a rich ecology of media falling outside state or corporate ownership. These have has been variously labeled 'radical media' (Downing, 1984), 'citizen media' (Rodríguez, 2001), or 'alternative media' (Atton, 2002). We prefer the term 'alternative media', which broadly involves "media production which challenges, at least implicitly, actual concentration of media power, whatever form these concentrations may take in different locations" (Couldry and Curran, 2003, page 7). Despite an increasing awareness of alternative media organizations, research has largely focused on alternative media in the wealthy 'global North'. This provides relatively benign circumstances for alternative media networks to emerge: there are plentiful resources and state repression or censorship is often not particularly harsh. 
But, what do alternative media look like in the 'global South' where state repression and censorship are more intense and resources less plentiful than in the developed world?

Little work has been done so far to consider this question. Existing comparative studies of media indicate that media organizations in relatively low-income countries and/or in situations constrained by sustained conflict have quite a radically different experience from those in more developed contexts (Frenzel and Sullivan, 2009). But, at the same time, there is a widespread assumption that the proliferation of ICT-based media would allow for alternative media organizations to develop easily in the 'global South'. This assumption has prompted investment in ICT projects by development NGOs and international donors in the last twenty years. Such tendencies have been questioned for "uncritically positing new media technology as deterministic of social progress" (Mudhai et al, 2009, page 1). Southern alternative media organizations often rely on significant support from Northern NGOs, donors, or funding. This creates unique challenges for Southern alternative media organizations. Rather than only challenging the power of large-scale media organizations, they also have to relate to, and in some cases to resist, the power exercised by their Northern partners and donors.

In this paper we address the lack of research into Southern alternative media by exploring differences between alternative media organizations in the North and the South. To do this, we have conducted research with two alternative media networks: IFIWatchnet and the Indymedia Centre in Africa (ICMA). These two networks bridged the North and South, not simply by establishing links between nodes in the North and the South. Rather, they attempted to create more substantial cooperation between multiple Northern and Southern nodes. They hoped this would facilitate the democratization and growth of the respective networks. However, we found that North-South cooperation often unveiled significant differences about how formal the organization should be: Northern media activists had a preference for highly decentralized and autonomous modes of organizing; whereas Southern activists usually focused on more formalized structures and processes which could garner funding from large foreign NGOs and aid agencies. This sometimes led to conflicts, which were often difficult to resolve because of a lack of a set of shared assumptions about the identity, form, and structures of accountability in each group associated with alternative media. This suggests that attempts to build North - South cooperation by transferring the model of alternative media with an emphasis on 'open source' and 'autonomist' principles are rather naïve. Instead, North - South alternative media cooperation appears to involve struggle between very different sets of assumptions about what alternative media is and how it is organized.

To make this point, we begin by reviewing existing studies of alternative media organizations, noting that this literature has rarely considered the important differences which might exist between alternative media in Northern and Southern contexts. We then outline our comparative case-based methodology for studying these differences. Next we look in more detail at our two case organizations of North-South cooperation: (1) IFIWatchnet, a civil society network established to link the work of groups critically 'watching' the activities of international financial institutions (IFIs) such as the International Monetary Fund and the World Bank and in which we focus on the shift of the network's 'headquarters' from North to South; and (2) IMCA, initiated as part of the global 'Indymedia' network. After outlining the history of these two cases, we focus on their identities, their organizational forms, and their structures of funding and accountability. We then move to a discussion in which these two cases are compared, and we draw out the differences between the Northern and Southern 
partners' assumptions. We conclude by suggesting some important areas for future comparative research on alternative media organizations facing clashing assumptions between Northern and Southern partners. We also draw out some implications for cross-context collaborations to sustain effective global alternative media-producing networks that are sensitive to these differences.

\section{Alternative media organizations}

Alternative media has been a neglected area of study, with few studies of this thriving sector existing prior to the 1990s (for some exceptions, see Downing, 1984; Gitlin, 1980; Halloran, 1970). In the past twenty years, however, there has been increasing recognition of the long history of alternative media and the important role it plays in the contemporary media landscape (Coyer et al, 2007). Because of the diversity of forms of alternative media, it is difficult to identify a set of stable characteristics that define it. Some argue that it is precisely because of the participatory and dynamic nature of alternative media that it is so difficult to tie it down in any meaningful sense (Gumucio-Dagron, 2004). This is because alternative media appears to always be in the process of evolving and overflowing any strict boundaries around what it could, or indeed should, be.

Despite these concerns, there have been a number of attempts to enumerate a cluster of common aspects associated with alternative media. These include: interactivity between producers and consumers, collective production, and a focus on everyday life (Enzensberger, 1974); the production of small-scale media involving horizontal (ie relatively nonhierarchical) patterns of communication (McQuail, 1986); a rejection of dominant political values, coupled with democratic or collectivist means of producing media; and a commitment to innovative creation of content (O'Sullivan, 1994). Alternative media is also associated with innovations in media use and distribution, being characterized by 'distributive use' and alternative forms of transmission, transformed social use, such as breaking down conventional producer-consumer relationships, and transformed communication processes, through an emphasis on networked horizontal links (Atton, 2002).

From these different lists of alternative media characteristics, it is possible to identify some common themes. The first is that alternative media typically have a radically different collective identity from other forms of media, involving a shared sense of what is specific, unique, and enduring to the organization or network (Whetten, 2006). While the specific form this takes may differ quite significantly, most alternative media organizations typically have an identity based around an overriding concern for producing social change (Gumucio-Dagron, 2004): from radical utopian desires to more modest aesthetic goals; and from claims for economic justice and social accountability, to reactionary right-wing desires. Alternative media has often evolved from grievances of social movement activists who find their view misrepresented in mainstream media (Cresswell, 1996; Routledge, 1997). The intent of alternative media thus is not simply to garner a large audience. Rather, it involves an attempt to create some kind of social and cultural change.

The second characteristic that seems to be unique to alternative media producers is the organizational form they adopt. An organizational form is made up of the goals of the organization, its authority relations, the technology it uses, and the markets it seeks to serve (Hannan and Freeman, 1984; Scott, 1995). Alternative media tends to emphasize the desirability of social change (as discussed above), organizing through more participatory and voluntary divisions of labour, using locally specific or 'tactical' media, and blurring the boundaries between producer and consumer. A central thread is the importance of participation as a core organizing principle, with a consistent 
theme in the literature being the active involvement of ordinary people or staff of campaigning organizations who are otherwise often marginalized in the production of media content. This involves encouraging contributions from active citizens, not being attached to a political party, a focus on and association with social movements, and an emphasis on 'prefigurative politics' (Downing, 1984, page 17).

The final distinctive aspect of alternative media organizations is their structure of accountability. This involves the answerability of an organization (ie who it must justify its actions to and how), and the enforcement of standards (Schedler, 1999). Many alternative media organizations would say that they are ultimately answerable to the communities that they set out to serve. These communities might be formally represented through a board or some other kind of governance mechanism typical of an NGO with intraorganizational hierarchies. Others might reject this kind of accountability, and instead seek to create accountability through consensus decision-making processes and direct democracy. Many alternative media organizations thus seek to break down structured links that typically exist between media producers and consumers, governors and the governed, through championing strongly participatory modes of decision making such as consensus processes. Such emphasis on radical democracy may be emphasized and enshrined in standards or codes of practice.

Alternative media organizations tend to differ significantly from more mainstream media organizations in terms of their oppositional identities, horizontal organizational forms, and participatory structures of accountability. However, we should note that the difference between alternative media organizations and other more mainstream forms is far from neat (Downing, 2001; Kim and Hamilton, 2006), Nevertheless, many of the radical characteristics of alternative media described above have themselves been further radicalized following the rise of ICTs (Atton, 2002; Lovink, 2002; Meikle, 2002; van de Donk, 2004). This has permitted the appearance of a whole new set of now well-known forms of alternative media which are largely web based, including the global independent media network or 'Indymedia' (Downing, 2001; Pickerill, 2007), OhmyNews in South Korea (Kim and Hamilton, 2006), and others. Many of these networked organizations foster identities that are radically boundary-less and open, influenced strongly by discourses associated with the open publishing and open source software movements and associated with 'autonomous geographies' (Pickerill and Chatterton, 2006). The assumption has been that ICTs permit the radical involvement and broadcasting of marginalized views and voices (Spicer and Perkmann, 2008). In addition, online ventures are considered to reframe and radicalize the ways in which these organizations operate, through placing further emphasis on networked and 'glocal' organizational forms (Sullivan, 2008). Bennett (2003), for instance, points out the importance of 'SPIN' organizational characteristics in online-based social movements: emphasizing 'Segmentation' (with fluid boundaries between hubs or nodes); 'Polycentricism' (or multiple hubs); 'Integration' (through horizontal structures of multiple or rhizomatic paths of communication); and 'networking' (effected by high degrees of connectivity). In addition, many online-based social movements have sought to push participatory accountability structures even further by actively changing the relationship of users to content. This has entailed a radical blurring of boundaries between users and producers through experimentation with open content and open editing processes, exemplified by the Indymedia slogan "Don't hate the media, be the media!" (Downing, 2001).

The language of participation, networks, openness, and engagement is now ubiquitous within these media-producing organizations, The principles of Indymedia, for example, are also made explicit in the so-called 'principles of unity'-a description of a radical democratic organizational identity, form, and accountability that is meant 
to enable the growth of the network without compromising local autonomy (Kidd, 2003). However, conflicts between the local and the global have continued to appear as codifications and standards may be interpreted in different ways, and powers to enforce a certain understanding may be limited. Discussing a conflict over funding from the Ford Foundation in the early years of the Indymedia Network, Pickard (2006a) pointed towards the problems that may arise when principles of local autonomy and network coherence clash. The 'principles of unity' could not prevent a very different reading of whether it was OK to receive funding from the Ford Foundation.

So far, it might be argued, this general problem has only been addressed in the contexts of a fairly limited set of studies and alternative media-producing situations. Indeed, the study of alternative media is often focused in Northern contexts (Hamilton and Atton, 2001) where the material conditions are relatively comparable. The little work that does focus on Southern contexts indicates that there indeed are some important differences between alternative media in the North and the South (eg Downing et al, 1995; Frenzel and Sullivan, 2009; Gumucio-Dagron, 2004; Kim and Hamilton, 2006; Park and Curran, 2000). Furthermore, Pickard's (2006a) study of the fate of Ford Foundation funding for Indymedia suggests that these differences may shape how Northern and Southern partners cooperate.

Given this relative paucity of work that researches alternative media specific to Southern contexts, in this paper we ask whether and how alternative media networks in the North and South differ. In particular, we are interested the potential differences between the identities, organizational forms, and structures of accountability expressed by alternative media organizations that are attempting to cooperate and collaborate in global alternative media networks.

\section{Methodology}

To explore differences between alternative media in the North and South, and how these played out during North - South cooperation, we adopt a comparative case-study methodology. This involves the selection, analysis, and systematic comparison of cases that we might expect to differ in theoretically significant ways (as described above). Single case studies have been favoured in the study of alternative media research: proving effective in investigating the dynamics and specificities of the work of alternative media in particular settings; in revealing rich information regarding each case; and sometimes in generating new concepts and theories (Eisenhardt, 1989). Here, however, we are interested in producing a relatively systematic analysis of how concepts and theories might generate and explain context-dependent differences in alternative media organizations operating as nodes within global media networks. A comparative case method involves the systematic analysis of the characteristics and dynamics specific to cases, coupled with analysis of the similarities and differences between cases along a range of relevant dimensions (Ragin, 1992). Such comparative approaches have proved useful in identifying differences in models of public broadcasting (Kueng-Shankleman, 2000), and are likely to be similarly useful for exploring differences in alternative media.

In order to explore differences between alternative media in Northern and Southern contexts, we selected two global networks which involved both Northern and Southern partners. These are IFIWatchnet, focusing on the shift of the network's headquarters from North to South, and IMCA which is part of the global Indymedia network. We have tried to ensure that these two media networks are sufficiently similar to warrant comparison: they use the same medium (the Internet), and share broadly similar left-leaning political orientations. Each involves substantial interaction between Northern and Southern actors. As we describe, a couple of years after 
its founding, the headquarters of IFIWatchnet moved from the North (London) to the Indymedia Centre Africa (the South (Montevideo), whilst continuing to serve a global audience and involving activists from multiple locations. On the other hand, the founding conferences of IMCA discussed in this paper were all based in the South (in Senegal, Mali, and Kenya). Nevertheless, Indymedia activists from the North played some role in developing IMCA. Both cases thus provide extremely interesting and potentially comparable examples of cooperation between North and South.

To compare these cases, we sought first to construct a comprehensive picture of each organization through extensive documentation, coupled with first-hand involvement and observation. In some cases this involved narrative accounts of organizational histories; in others, projects were documented through a collection of their output (eg exchanges on public domain e-lists). We also conducted semistructured interviews with participants in each of these cases. The interviewees were chosen because of their intense involvement in the case-study projects. Two of us, Zoe Young and Fabian Frenzel, were involved over the longer term as active creators of aspects of IFIWatchnet and IMCA, respectively, whilst also conducting 'action research' regarding these projects. Furthermore, participants in both cases were involved in the reviewing of this paper in line with the action research methodology adopted here (Kemmis and McTaggart, 2005; Kindon et al, 2007).

In analyzing the extensive data generated for each case, we began by developing a descriptive account of each organization. This involved broadly tracing the history of each of the cases, documenting how they developed, the core participants involved, and some of the central issues faced by each organization and their associated networks. We then developed a more analytical account of each of the cases, based on the three key dimensions of alternative media which we located in the literature: their identity, their organizational form, and their structures of accountability. These three dimensions were then used in a comparison of the similarities and differences between these organizations. In what follows, we detail the results of this analysis.

\section{IFIWatchnet}

IFIWatchnet.org was established in London in 2002 through the Bretton Woods Project (BWP). The IFIWatchnet homepage eventually presented news, campaigns, reports, and links to member groups, videos, and more. This information came mainly from preexisting network hubs such as the Bank Information Centre in Washington, Central and Eastern European Bankwatch Network in Prague, and the NGO Forum on the Asian Development Bank in Manila. These organizations were invited to participate in IFIWatchnet to share information and raise the profile of their work on IFIs, and in particular to establish a more visible and systematic presence on the web for research, perspectives, and campaigns from Southern civil society.

In October 2002 BWP applied to the Ford Foundation for funding for a one-year pilot project, and in early 2003 IFIWatchnet.org was established with a shared calendar and e-mail discussion 'D-group' that became the de facto governance structure for the nascent IFIWatchnet. The design was simple enough to be easy to access on dial-up connections in the South. The technical platform chosen for IFIWatchnet was Actionapps, an open-source content-management system (CMS).

With support from the Ford Foundation, a coordinator was employed for two days a week, supported by staff of BWP and also the Bank Information Centre. In 2005 the Ford Foundation continued its support for IFIWatchnet with a second two-year phase to be hosted in an organization based in the South. Several networks were put forward as potential new hosts, and the Instituto Tercer Mundo (ITeM) in Uruguay was selected from among the interested organizations. This decision was partly made because the 
majority of organizations in the network were from the North, and very few in were South America. One interviewee explained

"ITeM are better resourced, with more web access and people with the paid time to get involved, and provide materials online."

The management of the IFIWatchnet.org website was shifted from BWP - a small, horizontally organized, Northern research and lobbying network - to ITeM-a more hierarchically organized and information-technology-focused Southern NGO which had not until then been a member of IFIWatchnet. Initially, there was much optimism associated with the move, not least because BWP was happy to hand over technical aspects of the work to a more specialized team. However, the transfer process was hindered by the fact that nobody visited from either organization in the initial process.

The substantial role of the part-time core coordinator, more or less invisible from outside the network, was not effectively shifted into the new host. Her role in relationship building, managing informal interactions, and facilitating ownership was not effectively recreated or replaced within ITeM, and regional animators became somewhat neglected. As one interviewee said:

"like any network, it was about people and personalities who could sell an idea,

or push a certain idea, or a certain way of thinking."

It was this side of the organization of the network that was now missing, or at least not emphasized much. Instead, emphasis was now placed on maintaining and updating the technical infrastructure, such as the web platform. In 2006 ITeM developers shifted the database from the original Actionapps software to the open-source Drupal CMS. The decision to invest time and resources in this shift was perceived within ITeM as technical, responding to the growing profile and utility of Drupal. The decision involved consultation with the Association of Progressive Communications and the IFIWatchnet steering committee, but not with IFIWatchnet's animators, who mostly used the CMS.

IFIWatchnet's funding was due to run out in 2007. A year's extension to the Ford Foundation grant was allowed for ITeM to explore further funding opportunities. Suggestions included subscriptions by participating groups and networks, and selling appropriate ethical advertising. These proposals did not get far, ostensibly because member organizations had not really seen the point of a network that expected substantial extra work by their staff and showed only limited progress towards information sharing.

\section{Organizational identity}

Several key aspects of the political identity motivating IFIWatchnet can be identified. Central for its Northern founders was the idea of a networked information-sharing structure that could be enabled by ICT and used to enhance counterhegemonic struggle to influence development discourses. Positioned as challengers of the power of dominant donors to shape public banking institutions' policies and discourses, the founders' political backgrounds can be located in the global justice movement, focusing on critique of the international finance sector, environmental degradation, unpayable 'Third World' debt, and neoliberal structural adjustment.

With the move of IFWatchnet from its former base in London to a new location in the South, some changes in the nature of the project were apparent. Although there was great overlap in an understanding of IFIWatchnet as counterhegemonic globally, some more intangible elements of this identity came into conflict with parts of the new host organization. To some degree this may have been because ITeM's technical work processes were more formalized than those in BWP. In addition, since most ITeM staff were only peripherally involved in international IFIWatch communities, they did not 
attend the World Bank/IMF annual meetings or engage in the cross-network policy communications that are BWP's everyday work. The result was that, without strategic efforts to bridge this gap, communications with those networks became less intimate, collaborative, and effective. As a result, "quite often, things don't happen", as one interviewee expressed it, which was "a very slow, frustrating way to work."

So although the move introduced a more 'professionalized' identity, it also led to a sense of distance between managers of the networking tools and those directly campaigning on IFIs. Staff in ITeM claimed independence in the site-management process. Some interviewees told us that the content of IFIWatchnet became simply another facet of ITeM's strategic technical work; a website to promote certain political perspectives and generate grant funding. ITeM's sense of independence in terms of claiming the right to manage the network in a particular way was partly informed by a deep-seated anticolonial identity amongst some staff in Uruguay. In one interview, reference was made, without prompting by the interviewer, to British colonial involvement in Uruguay's past, which the interviewee at ITeM used to explain some of the communication problems the network had been experiencing.

\section{Organizational form}

When IFIWatchnet initially emerged in London, it had a fairly flat organizational structure. This informality was a practical way of working to a low budget, with a few people collaborating on a wide range of tasks, embodying oversight at the same time as communications and some of the more traditionally 'low-status' tasks involved. Building networks and communities for information sharing and coalition building was seen as a productive political act in and of itself. The aim was to produce 'warm' atmospheres of supportive and responsive collaboration among an 'adhocracy' of those committed to the networking project. This was frequently contrasted with the 'colder' feeling of more formal structures. It was felt that mutual understanding between core people involved in delivery of a broad network like IFIWatchnet was essential. This included respect for different organizational set ups and how they shape participation, individual motivations, and assumptions.

Before the move to ITeM, informality was embodied both in the way the project was formed in London and also in the networking with partners across the world by the Northern founders of the project. The adoption of ICTs was intended as mediasharing infrastructure to enhance this informal development of networks, and was based in a social and political convergence prior and parallel to the technical networking. As the project moved to Uruguay, arguably a different, more instrumental and technical, understanding of the role of ICTs emerged, exemplified by the management of the change of CMS. Importantly, the problem did not lie in the new CMS but, rather, in the assumption that decisions about CMS are merely technical and hence do not require consultation and building on others' experience. As one interviewee said, during the move to the South "a lot of the sense that this is a network not a technical platform" got lost. Attitudes towards ICTs arguably indicate different organizational forms. For another interviewee this was not about a "North-South split", as she expressed it. However, she continued to say that

"if you want it [the network] to be more representative, then you need to put more work into supporting and encouraging people... and that sort of implies more people involved really; and if there are more people involved then I think you do need to have somebody who's pushing that, and driving that, and keeping people motivated and so on." 
With the move from the North to the South this precise engagement with people became deemphasized, as the network became more technically focused and less engaged with network-building activities and informal interaction.

The movement drew out a clash between a more informal organizational form with a focus on networking championed by Northern activists and a more formalized one with a focus on technical issues championed by Southern activists. This clash became more evident on a number of occasions. One instance was when some Northern activists collaborated with each other to explore possibilities to further develop Actionapps, the CMS that was used for the IFIWatchnet website at that time. One activist told us that "ITeM then got involved, hysterically as always, sending a message to $[\mathrm{xxx}]$ telling him that he's fucked up things." This example of an overheated discussion is an indication of the strains in the network at that time.

\section{Accountability}

IFIWatchnet's move to the South was proposed by its initiators to the Ford Foundation as an indicator of their intent to maximize Southern involvement in IFIWatchnet. In other words, a project based on critique of global financial institutions established in the North ideally should not be based in Northern centres of finance capital like London. It was felt that by locating in the South, the network could practise its responsibility and broader accountability to the global movement it served.

However, this move had unforeseen implications. When the network was based in the North, systems of accountability were largely based on dense networked relationships. Accountabilities and responsibilities were negotiated and usually founded upon personal trust. This system of accountability was relatively informal in nature. However, when the network moved to Montevideo, it became far more formalized in nature and specific task responsibilities became more circumscribed and specified. As a result, tasks that did not fit clearly with circumscribed responsibilities could be disregarded. Similarly, when Northern activists intervened in others areas of responsibility (such as happened with the CMS, mentioned above), there was a strong negative reaction from the Southern partners. What this suggests is that different understandings of what it meant to be accountable and responsible for an activity or outcome gave rise to some important clashes.

The clashes between the more informally goal-oriented Northern and more formally process-oriented Southern groups evolved in a way which limited functionality of the network as a whole to such an extent that many in the originating project discontinued their engagement. It is unknowable to what extent outcomes might have been different had IFIWatchnet relocated to an organization with a profile similar to ITeM's - technically focused, more hierarchical-but still based in London; nor whether better coordination and technical systems would have resulted in more users engaging with the network. As one interviewee from the North said, "we are all suffering from the same capacity problems, not really finding sufficient time for working on IFIWatchnet." That is, there are capacity issues at work that do not necessarily have anything to do with North-South relations. However, as our research on IFIWatchnet shows, the move of the network-management role from North to South did create a range of problems for this alternative media organization.

\section{Indymedia Centre in Africa (IMCA)}

Indymedia is a global network of independent media centres (IMCs) founded in Seattle in the context of the emerging global justice movement (GJM) and its 'coming out party' which closed the Ministerial Meeting of the World Trade Organization in November 1999. It is bound up with a broader desire to foster a 'globalization from below', 
or what has been described as 'grassroots globalization' (Appadurai, 2001). Indymedia represents itself as a tool for the networking of struggles and the convergence of activists across the world against neoliberal globalization, as well as a social movement to democratize the production of news media (Mamadouh, 2004a; Pickard, 2006b; Pickerill, 2007). After a period of rapid 'organic' growth effecting the proliferation of network nodes in various locations in the first months and years of its existence, Indymedia became concerned about the radical North - South imbalance of its growth (Halleck, 2002). In 2003 the whole continent of Africa was represented by only four IMCs while the UK alone had thirteen (Frenzel and Sullivan, 2009; Mamadouh, 2004b). Mirroring the global 'digital divide', the lack of IMCs in Africa was understood as a challenge to Indymedia by some of its members. Indymedia's claim to 'globalize from below' suffered from the conspicuous dominance of Northern nodes in the network. At the same time, ICT-based media promised to have a great potential to support processes of democratization in Africa. In 2003, following an initiative of activists from the IMC Ambazonia (Cameroon), an IMC run by diaspora activists in Europe, four exist-ing African IMCs, together with members from across the global network, founded IMC Africa (IMCA). IMCA was inspired by the idea to foster the development of Indymedia network nodes in Africa through support, knowledge exchange, and networking. Initially a network based on an e-mail listserv, IMCA soon started organizing for a conference in Senegal to be held in March 2004. The aim of the conference was to bring together journalists and media activists from Africa, and to train them in the use of ICTs as independent media activists. This was intended to initiate the foundation of more IMCs in various places in Africa.

Within the global Indymedia network this idea was controversial. The GJM had one of its origins in the movements against neoliberal development policies imposed under the 'Washington Consensus'. The GJM was inspired by the idea to go 'beyond development' (Escobar, 1992; Esteva and Prakash, 1998). Indymedia activists consequently showed some reservations concerning embarking on a project that tried to 'bring' the idea of Indymedia to Africa, being highly conscious of the colonial undertone of this approach. To operate with metaphors like 'open space', used frequently in ICT and GJM discourses, in postcolonial contexts had already been criticized as 'double colonization' (Chesher, 1994; Flatz, 1999; Frenzel and Sullivan, 2009). Significantly, a funding request to Indymedia global for delegates' plane tickets was blocked by the IMC Uruguay on the grounds that linking the creation of new IMCs to a transfer of funds from the global Indymedia would create 'dependent' rather than 'independent' media (Indymedia, 2004). The project had support from the existing African IMCs and from many other IMCs and went ahead without the financial support from Indymedia global. The activists in IMCA organized their first conference in Dakar in 2004 and two subsequent conferences in 2006 and 2007 in Bamako and Nairobi.

From the outset, IMCA faced the challenge of a lack of equivalent resources in the African context. To combat this, IMCA adopted models more closely associated with conventional NGO funding structures. Funding was sought and found through donors active in ICT and North-South cooperation, and was used to finance travel costs of African participants. IMCA also often relied on a broader set of local partners, involving NGOs, development institutions, and universities. This caused a series of controversies between Northern and Southern participants in the IMCA and with the broader Indymedia network. In the 2006 IMCA conference in Bamako, Mali, some local organizing work in preparation for the conference was done from the offices of a media NGO called Geek Corps, whose operations were financed by USAID, the US government development agency. This involvement caused strong concerns among Indymedia members from Latin America: 
"I was very disturbed with the information that IMC Bamako room was co-financed by USAID .... USAID was one of the main US agencies financing ideological apparatus during Latin American dictatorships in the 60s and 70s" (Indymedia, 2006).

Despite a level of misunderstanding causing this particular conflict (IMC Africa did not receive financial support from USAID), this conflict had a base in very different organizational identities of IMCs in Latin America and West Africa. Local organizers in Mali had very little concern about working with USAID, as the French government's postcolonial influence in this part of Africa was considered much more problematic than US influence.

Despite the increasing understanding and reflection within IMCA and Indymedia regarding particularities of the African context, conflicts occurred repeatedly over organizational patterns and funding during its existence-often infringing on the working of the project. As we attempt to show in the section that follows, these features of IMCA's history enable us to tease out some strands relevant to possible further analysis, reflection, and comparison. We look particularly at the ways these conflicts emerged during IMCA conferences between Northern and Southern participants.

\section{Organizational identity}

Participants agreed to a framework in which the conferences were to be radically democratic, aspiring to relatively nonhierarchical organizational and communications structures, following not simply the 'principles of unity' but more implicit, everyday, understandings of politics. For some Northern participants this included the politics of housekeeping, cooking, washing dishes, and other tasks which are frequently gendered as part of a feminized domestic sphere. As some of the Southern (female) participants wryly expressed, 'African men' were not used to the idea of doing the dishes, while Northern male participants were likely to at least pay lip service to the importance of these activities. The shared rejection of global capitalism and its consequences did not extend to a shared discourse on politics of the everyday. In other instances, political cultures clashed as activists from the North who self-identified as 'queer' met openly homophobic participants from the South. One Northern participant expressed this in an interview:

"[some] people have been guided by this idea that gayness, queerness, homosexuality that is bad, that is wrong that is evil. So that has been really hard, that has been hard."

Some of the perceptions of African poverty held by Northern participants clashed considerably with Southern perspectives. Some Northern participants pressed the group for close relations with 'slum dwellers' and were actively searching for projects that engaged with slums. In Nairobi there was a direct conflict when some Northern participants questioned the gated-community type of location of the conference and asked for a relocation of the project "into the slums". For African participants in the project, it involved "glorifying poverty and glorifying ghetto life" which expressed the naivety of Northern participants. One participant from Nairobi explained this point in more depth:

"in the Western context if you wear very very dirty jeans, you have a cap with Che Guevara on it, and you hang out in these abandoned houses then you really feel you are separate from society and you are doing something.... in Nairobi you are never going to find an abandoned house to hang out in and if you want to see real change... [y] ou then need to work closely with Kenya Indymedia to understand this whole notion of poverty." 
The request to relocate to the slums arguably indicated an antipathy towards working with African activists who were middle class. It seemed that the Northern participants were actively searching to find in their African partners the images of Africa they brought with them.

\section{Organizational form}

Following the experiences of difficulties in aligning organizational form between different contexts, IMCA came to the conclusion that participants first needed to learn about forms of horizontal decision making. In an e-mail exchange during the preparation process for the Nairobi IMCA conference an organizer said:

"Since at the core of the whole work of INDYMEDIA IS THE CONCEPT OF HORIZONTAL/PARTICIPATIVE DEMOCRACY, X will run workshops before the 13th. The hope is that the skills acquired in how to organize along consensus lines could be put to practice in all the workshops in tech skills" (Indymedia, 2007, capitalization in original).

The focus on horizontality led to some Northern participants assuming powerful roles of teachers and instructors. By doing this, IMCA arguably replicated developmental approaches in which an advanced Northern mode of organization is to be diffused into Africa by Northern experts. One interviewee reflected on the consequences of this approach:

"I think to an extent a lot of us in that first week had our work clearly cut out, but some of us didn't really have it clearly cut out. And then at that foundational level they pretty much established themselves in that mentality of receiving. I think you can bear me witness that that seems to have endured pretty much up to the very last day."

As Northern teachers attempt to instruct Southern participants about horizontal and participatory organizational forms, there was a sense that some Southern participants became 'spectators' in the process.

\section{Accountability}

The fact that most of the funding for IMCA came from the North might be not surprising. This, however, led to imbalances between participants, even within the relatively informal setting of IMCA. Some Southern participants often asked for resources from the group to pay for mobile phone costs, transport expenses, and copy costs. For many Northerners these requests were questionable and even 'selfish', because they were seen as private consumption needs rather than needs for the project. This notion of 'selfishness' is important as it belies the Northerner's assumption that political work should be 'unselfish' or charitable. The radically differing understandings of what constituted legitimate use of funds for political work made it difficult to operate within formally horizontal structures like a finance committee. One Nairobi activist thought that for many African participants certain organizers appeared "like gatekeepers of the money.... There are resources there but there are people standing in the way so we have to push them so we can reach these resources." In the process, activists from the North became conscious about the material basis of their 'unselfishness'. A Northern activist said

"So here I am from the US, I am a white female, and I am coming with a lot of tools, a lot of electronics, a lot of media and so that just sets up a whole series of dynamics and conversations and things to sort through." 


\section{Discussion}

In the case of IFIWatchnet, many of the Northern founders understood it to be a global network with a relatively informal and nonhierarchical organizational form. with informal trust-based forms of accountability. In contrast, the new Southern hosts understood IFIWatchnet to be a technical platform that should be organized in a more hierarchical way in order to comply with more formal modes of accountability. In the case of IMCA, we found that Northern participants saw it as a radical political movement that was informally or horizontally organized and should be based on passionate political accountability. In contrast, Southern participants saw IMCA as more of an NGO involving more formal structures and with restrictive forms of accountability controlled by Northern participants.

Although there are significant differences between the two cases, there are some striking aspects of similarity. Northern participants appear to see alternative media as having a radical identity, being organized in a more informal and horizontal way, and having more trust-based or commitment-based forms of accountability. In contrast, Southern participants tend to emphasize a more 'mainstream' identity, formalized modes of organization, and modes of accountability more tied to foundations and donors. The organizational characteristics which we found among Northern participants very much reflects other accounts of alternative media participants who see themselves as agents of radical social change, work with decentralization and flexible networks, and use trust-based forms of accountability (eg Atton, 2002). However, Southern participants approached alternative media in a very different way which could be said to resemble more closely 'mainstream' media.

There are at least three possible reasons we can identify for these differences between the Northern and Southern activists' orientation to alternative media. The first reason that emerges clearly in each of the cases is the differential access to resources. Northern activists tended to rely on a broad range of sources of funding and other resources, such as private means of support, help from friends, paid part-time jobs, as well as donor funding. In contrast, Southern activists frequently relied heavily, often exclusively, on formal sources of funding, such as foundations, and developed an organizational identity that was more akin to formal organizational and accountability structures. The second reason for this difference is the differing activist cultures that media activists work within. The Northern activists tend to be part of activist cultures which emphasize informal trust relations, broad participation, and radical democratic involvement based on temporary projects. In contrast, many of the Southern activists were immersed in activist subcultures which tended to operate through more formal NGO structures. These two cultures were reflected in how activists sought to build up alternative media organizations. The third reason for these divergences in Northern and Southern orientation to alternative media is the different political opportunity structures which media activists face in the North and South. Most of the Northern media activists faced relative benign opportunity structures which are characteristic of liberal societies and provided them significant space for airing their views and engaging in political action. In contrast, Southern activists typically faced more difficult opportunity structures which may have limited their political action and the airing of their political voices.

The different assumptions about identity, form, and accountability in conjunction with the different patterns of resource distribution, activist culture, and political opportunity structure created significant barriers for cooperation between Northern and Southern activists. In the case of IFIWatchnet, there was a significant clash around how the network should be managed and whether more attention should be paid to building a technical platform or fostering network interaction. Failure to resolve this 
ultimately led to many participants losing interest in the project and moving onto new networks and media-sharing tools. In the IMCA case, the differences created some conflicts around where events were held, how they should be run, and who should have access to resources. Although there was not the kind of loss of interest we found in the IFIWatchnet case, there were ongoing concerns that infused the project.

\section{Conclusion}

In this paper we have investigated the differences between alternative media in the North and South and how these differences influence cooperation. Focusing on IFIWatchnet and IMCA, we found that Northern participants were broadly oriented towards more 'horizontal' modes of organizing while Southern participants tended to draw on more 'vertical' or hierarchical modes of organizing. This suggests that we need to move away from broad claims that attribute particular organizational characteristics to alternative media throughout, independent of context. From our small sample, it appears that understanding alternative media in the South requires the investigation of a range of organizational identities, forms, and structures of accountability. More broadly, this recognition of diversity offers a clear rebuke to recent techno-utopian visions of the Internet which tend to see it as creating a natural drive towards horizontal forms of social interaction and collaboration (eg Shirky, 2008). Based on our current study, it appears that the network modes of organizing are actually primarily the providence of Northern activists. In the South, more 'vertical' models of organization appear to have been used to put new ICTs to work.

The different assumptions of Northern and Southern participants had a profound influence on cooperation. The lack of a shared identity, organizational form, and accountability can produce misunderstandings and conflicts which are relatively rare within local organizing contexts of 'autonomous geographies' (Pickerill and Chatterton, 2006). We highlighted how conflicts over projects, the distribution of funding, and the broader survival of the network were shaped by clashing assumptions and modes of organizing. This meant that North-South cooperation was often underpinned by deeper struggles around what each of the organizations were and how they should operate. Furthermore, there was a propensity to overlook differences in alternative media networks among participants. We assume that Northern activists tend to understand their preferred organizational forms as being democratically advanced and 'naturally' facilitating global involvement and cooperation. However, these 'horizontal' structures clash with the locally specific needs of many Southern participants to garner resources through funding from more formal NGOs and foundations. What this suggests is that, far from being a natural basis for facilitating spontaneous cooperation, the horizontal structures championed by many media activists may actually be a barrier to cooperation in some cases. Equally, 'vertical' modes of organization that are encouraged by various factors in the South can certainly be an important barrier to cooperation. But Northern activists clinging to the assumption that horizontal modes of organizing are naturally superior at facilitating cooperation may hinder cooperation as well. High levels of commitment to the ideals of horizonalism can mean that Northern alternative media organizations overlook the particularity of their contexts. The result is that cooperation might reproduce developmental logics and unequal power relations between Northern and Southern participants. An outcome akin to what has been criticized as 'double colonization' (Chesher, 1994; Flatz, 1999) might result from this.

While it is important, and somewhat inevitable, that global networking of alternative media continues, this process may face significant difficulties. In particular, these difficulties may arise out of different sets of assumptions of what alternative 
media organization is and how it should be organized. We should be clear that our sample is limited to two networks that involve Northern and Southern activists. This makes our broader claims about North-South differences somewhat preliminary. In order to consider whether our findings are more generally applicable, it would be vital to examine other examples of North - South cooperation in alternative media. By considering other cases, it would be possible to explore the dynamics of cooperation and conflict. Future studies should reflect upon the issues that came to the forefront in this study, to complement the research presented here. In this way, research can play an active role in enhancing and improving future cooperations. Alternative media will have to join the ongoing learning processes of meetings like the World Social Forum, where many of the issues discussed here have been a constant feature of organization (Boehm et al, 2005; Keraghel and Sen, 2004; Wallerstein, 2004). We would argue that it is only by learning from these problematic encounters that real progress towards higher degrees of global cooperation can be achieved.

Acknowledgements. The authors would like to thank research participants from IFIWatchnet and IMCA for their contributions to the research process and the anonymous reviewers for their valuable comments. The research underpinning this paper emerged out of a project entitled "Alternative Media and Public Action: Organising the Global Alternative Networks", which was funded by the UK's Economic and Social Research Council (Grant RES-155-25-0029).

\section{References}

Appadurai A, 2001 Globalization (Duke University Press, Durham, NC)

Atton C, 2002 Alternative Media (Sage, London)

Bennett W L, 2003, "New media power: the Internet and global activism", in Contesting Media Power: Alternative Media in a Networked World Eds N Couldry, J Curran (Rowman and Littlefield, Lanham, MD) pp $17-38$

Boehm S, Sullivan S, Reyes O, 2005, "The organisation and politics of social forums" Ephemera: Theory and Politics in Organization http://www.ephemeraweb.org/journal/5-2/5-2index.htm

Chesher C, 1994, "Colonizing virtual reality", http://cultronix.eserver.org/chesher/

Couldry N, Curran J (Eds), 2003 Contesting Media Power: Alternative Media in a Networked World (Rowman and Littlefield, Lanham, MD)

Coyer K, Dowmunt T, Fountain A, 2007 The Alternative Media Handbook (Routledge, London)

Cresswell T, 1996 In Place Out of Place: Geography, Ideology, and Transgression (University of Minnesota Press, Minneapolis, MN)

Downing J, 1984 Radical Media: The Political Experience of Alternative Communication (South End Press, Boston, MA)

Downing J, 2001 Radical Media: Rebellious Communication and Social Movements (Sage, Thousand Oaks, CA)

Downing J, Mohammadi A, Sreberny A (Eds), 1995 Questioning the Media: A Critical Introduction 2nd edition (Sage, Thousand Oaks, CA)

Eisenhardt K, 1989, "Building theories from case study research" Academy of Management Review $14532-545$

Enzensberger H, 1974 The Consciousness Industry on Literature, Politics and the Media (Seabury Press, New York)

Escobar A, 1992, "Imagining a post-development era? Critical thought, development and social movements", Third World and Post-colonial Issues Social Text 31/32 20-56

Esteva G, Prakash M S, 1998, "Beyond development, what?" Development in Practice 8 280 - 296

Flatz C, 1999, "Africa in the fast lane of the highway development?" [original in German], http://translate.google.co.uk/translate?js=y\&prev=_t\&hl=en\&ie=UTF-8\&layout=1 \&eotf=1\&u=http\%3A\%2F\%2Fwww.heise.de\%2Ftp\%2Fr4\%2Fartikel\%2F5\%2F5459\%2F1.html $\& \mathrm{sl}=$ auto $\& \mathrm{tl}=\mathrm{en}$

Frenzel F, Sullivan S, 2009, "ICTs and democratic development in the Project IMC Africa", in African Media and the Digital Public Sphere Eds O F Mudhai, F Banda, W Tettey (Palgrave Macmillian, Basingstoke, Hants) pp 165-182

Gitlin T, 1980 The Whole World is Watching: Mass Media in the Making and Unmaking of the New Left (University of California Press, Berkeley, CA) 
Gumucio-Dagron A, 2004, "The long and winding road to alternative media", in The SAGE Handbook of Media Studies Ed. J Downing (Sage, Thousand Oaks, CA) pp 41-64

Halleck D, 2002, "Indymedia: building an international activist Internet network" International Symposium of Interactive Design http://newmedia.yeditepe.edu.tr/pdfs/isimd_04/12.pdf

Halloran J, 1970 Demonstrations and Communication: A Case Study (Penguin Books, Harmondsworth, Middx)

Hamilton J, Atton C, 2001, "Theorizing Anglo-American alternative media: toward a contextual history and analysis of US and UK scholarship" Media History 7119 - 135

Hannan M, Freeman J, 1984, "Structural inertia and organizational change" American Sociological Review 49149 - 160

Indymedia, 2004, "[IMC-Seattle] FYI [Imc-finance] Proposal 2004-B Dakar Conference request BLOCKED”, Archive of Indymedia Mailing Lists, http://archives.lists.indymedia.org/imc-seattle/ 2004-March/004732.html

Indymedia, 2006, "[Imc-communication] USAID”, Archive of Indymedia Mailing Lists, http://lists.indymedia.org/pipermail/imc-communication/2006-January/0121-y7.html

Indymedia, 2007, “[Imc-Africa] Information from Nairobi”, Archive of Indymedia Mailing Lists, http://lists.indymedia.org/pipermail/imc-africa/2006-October/1005-lr.html

Kemmis S, McTaggart R, 2005, "Participatory action research" in The SAGE Handbook of Qualitative Research Eds N K Denzin, Y S Lincoln (Sage, Thousand Oaks, CA) pp 350-375

Keraghel C, Sen J, 2004, "Explorations in open space: the World Social Forum and cultures of politics" International Social Science Journal 56(182) 483-493

Kidd D, 2003," The Independent Media Center: a new model" Journal of the World Association for Christian Communication http://www.waccglobal.org/en/20034-indymedia/619-The-IndependentMedia-Center-A-new-model.html

Kim E, Hamilton J, 2006, "Capitulation to capital? OhmyNews as alternative media" Media, Culture and Society $28541-560$

Kindon S L, Pain R, Kesby M (Eds) 2007 Participatory Action Research Approaches and Methods: Connecting People, Participation and Place (Routledge, London)

Kueng-Shankleman L, 2000 Inside the BBC and CNN: Managing Media Organisations (Routledge, London)

Lovink G, 2002 Dark Fiber: Tracking Critical Internet Culture (MIT Press, Cambridge, MA)

McQuail D, 1986 New Media Politics: Comparative Perspectives in Western Europe (Sage, London)

Mamadouh V, 2004a, "Internet, scale and the global grassroots" Tijdschrift voor Economische en Sociale Geografie 95482 - 497

Mamadouh V, 2004b, "The North South digital divide in transnational grassroots networks: open publishing and the Indymedia network" International Conference ICTS and Inequalities: The Digitial Divides http://irene.asso.free.fr/digitaldivides/papers/MAMADOUH_Virginie.pdf

Meikle G, 2002 Future Active: Media Activism and the Internet (Pluto Press, New York)

Mudhai O F, Banda F, Tettey W (Eds), 2009 African Media and the Digital Public Sphere (Palgrave Macmillian, Basingstoke, Hants)

O’Sullivan T (Ed.), 1994 Key Concepts in Communication and Cultural Studies 2nd edition (Routledge, London)

Park M, Curran J, 2000 De-westernizing Media Studies (Routledge, London)

Pickard V W, 2006a, "United yet autonomous: Indymedia and the struggle to sustain a radical democratic network" Media, Culture and Society 28315 - 336

Pickard V W, 2006b, "Assessing the radical democracy of Indymedia: discursive, technical, and institutional constructions" Critical Studies in Media Communication 23 19-38

Pickerill J, 2007, “'Autonomy online': Indymedia and practices of alter-globalisation” Environment and Planning A $392668-2684$

Pickerill J, Chatterton P, 2006, "Notes towards autonomous geographies: creation, resistance and self-management as survival tactics" Progress in Human Geography 30730 - 746

Ragin C C, 1992, "Casing' and the process of social inquiry”, in What is a Case? Exploring the Foundations of Social Inquiry Eds C C Ragin, H S Becker (Cambridge University Press, Cambridge) pp $217-226$

Rodríguez C, 2001 Fissures in the Mediascape: An International Study of Citizens' Media (Hampton Press, Cresskill, NJ)

Routledge P, 1997, "The imagineering of resistance: Pollock Free State and the practice of postmodern politics" Transactions of the Institute of British Geographers, New Series 22 359-376

Schedler A, 1999, "Conceptualizing accountability", in The Self-restraining State: Power and Accountability in New Democracies Ed. A Schedler (Rienner, Boulder, CO) pp 13-18 
Scott W, 1995 Institutions and Organizations (Sage, Thousand Oaks, CA)

Shirky C, 2008 Here Comes Everybody: The Power of Organizing Without Organizations (Penguin Books, New York)

Spicer A, Perkmann M, 2008, "Translating an organizational form: the case of Indymedia", paper presented at McGill University, Canada (June); copy available from André Spicer, Warwick Business School, Coventry

Sullivan S, 2008, "Conceptualising glocal organisation: from rhizome to E=mc2 in becoming posthuman", in Metaphors of Globalization: Mirrors, Magicians and Mutinies Eds M Kornprobst, V Pouliot, N Shah, R Zaiotti (Palgrave Macmillan, Baskingstoke, Hants) pp 149-166

van de Donk W (Ed.), 2004 Cyberprotest: New Media, Citizens, and Social Movements (Routledge, London)

Wallerstein I, 2004, "The dilemmas of open space: the future of the WSF" International Social Science Journal 56(182) 629-637

Whetten D, 2006, "Albert and Whetten revisited: strengthening the concept of organizational identity" Journal of Management Inquiry 15 219-234 
Conditions of use. This article may be downloaded from the E\&P website for personal research by members of subscribing organisations. This PDF may not be placed on any website (or other online distribution system) without permission of the publisher. 